\title{
Analysis of purse seine fisheries business feasibility in coastal fishing port Pondokdadap, Sendang Biru, East Java, Indonesia
}

Imam Nurul Firdaus ${ }^{1}$, Dony Prasetyo ${ }^{1, *}$, Ganjar Adhywirawan Sutarjoㅇ, David Hermawan ${ }^{1}$

${ }^{1}$ Aquaculture Department, Faculty of Agriculture and Animal Science, University of Muhammadiyah

Malang, Indonesia

*donyprasetyo@umm.ac.id

*corresponding author

ARTICLE INFO

Keywords:

Hindia ocean

Fisheries

Purse seine

\section{ABSTRACT}

A purse seine is a fishing tool made of nets which are operated by circling the hordes of fish to a bowl-shaped tool at the end of the fishing process and is commonly used to catch pelagic fish by fishermen at UPT PPP Pondokdadap. The purpose of this study was to determine the technical aspects and income of the purse seine vessels in Sendang Biru village and to analyze the feasibility of the purse seine fishery business in the Sendang Biru village. This research was conducted from May to June 2020 at UPT PPP Pondokdadap, Sendang Biru hamlet, Malang Regency. The research sample was taken by purposive sampling and the data used were primary and secondary data. Data analysis using descriptive analysis and business financial analysis. The results of the calculation of the business analysis and investment on the purse seine ship found a profit of IDR 1394798872 , R/C of 43, PP of 13 months, ROI of 92, NPV of IDR 90337780 072, IRR of $633.8 \%$, and Net B/C is 61 . The results show that the purse seine fishery business meets the requirements and is still feasible to be implemented.

How to cite:

Firdaus IN, Prasetyo D, Sutarjo GA, Hermawan D. 2020. Analysis of purse seine fisheries business feasibility in coastal fishing port Pondok Dadap, Sendang Biru, East Java, Indonesia. IJOTA, 3(1): 40-52.

DOI: https://doi.org/10.22219/ijota.v3i1.13316

\section{Introduction}

The coastal fishery port, Pondokdadap is located in Tambak Rejo, Sumber Manjing Wetan, Malang. Located in the southern sea of Java, Pondokdadap Port has potential in abundant of fishery 
potential resources. The abundant fishery resources in PPP Pondokdadap have attracted people from other areas to become fishermen. The number of fishing vessels in Sendang Biru reached 606 units including 352 hand-fishing vessels, 166 units of jukung and kunting boats, and 86 purse seine vessels (UPT.PPP Podokdadap, 2019).

The livelihoods of the people in Sendangbiru hamlet are fishermen, there are some of the people who are boat owners and some are ship crew on purse seine vessels. Ships with purse seine fishing gear are commonly known as slerek nets. On average, the purse seine in Sendangbiru uses two boats, which consist of a net boat that operates fishing gear and a hunting boat that functions as a tow rope and a place to put fish catches (Hermawan et al., 2016).

On boats with purse seine fishing gear in Sendangbiru, the fish caught include swallow fish (Decapterus russellI), red-tailed flying fish (Decapterus tab), lemuru fish (Sardinella lemurk), these fish are generally captured on a ship with a purse seine fishing gear. From the fisheries statistical data at UPT PPP Pondokdadap on purse seine fishing gear in Sendangbiru village, production is uncertain every year or it can be said that in 2015, the production of zinc tonbap purse fish, a tonkap purse is 3,306 t, 2018 is 10,260 t, 2019 of 8,191 t (UPT.PPP Podokdadap, 2019).

The causes of the ups and downs in the amount of annual production are caused by several factors, including the number of purse seine gears at sea and also the GT size of the purse seine vessels and the length of the nets and the number of crew members which affect the catch of each vessel differently. In addition, rainfall, high waves and bad weather affect the purse seine fishermen's trips which cause fewer trips compared to the previous year (Hermawan et al. 2012). According to Fattah et al. (2017), factors that become challenges for fishermen are weather, sea conditions and the presence of fish. In addition, marine fish catches are generally influenced by the number of fleets, fishing gear and fishermen. This affects the income of purse seine fishermen, the income of purse seine fishermen in Sendangbiru are uncertain because the production of fishermen's catch fluctuates and fishermen's income only depends on the catch of the purse seine boat. The objectives of this study were to determine the technical aspects and income of the purse seine vessels, and to analyze the business feasibility of the purse seine vessels in the Sendangbiru.

\section{Material and methods}

\subsection{Methods}

This study was conducted at Pondokdadap Fishery Port, Tambak Rejo, Sumber Manjing Wetan District, Malang, Indonesia. Data collection was collected from May to June 2019. The present study used a survey method, which engaged a population and employed a cake-commissioner as the main data collection tool. The survey method was carried out when the data was actually already in the field or the object of research was clear. The collected data were obtained from primary and secondary research. Primary data came from direct interviews using questionnaire to purse seine fishermen at Pondokdadap Fishing Port. Secondary data were obtained from the Pondokdadap Coastal Fisheries Port office. Sampling of purse seine fishermen used a purposive sampling method which was included in the non-probability sampling technique. The purposive sample was taken based on the consideration of the researcher (Eriyanto, 2007). This purposive method was carried out based on the consideration of respondents who are directly involved in fisheries business and were willing to be interviewed and able to answer research questions. 


\subsection{Data analysis}

In this study, the data analysis used descriptive analysis and business feasibility analysis. Descriptive analysis is data analysis by describing or describing the data that has been collected from observations in accordance with the reality in the field. Business feasibility analysis is an attempt to determine the feasibility or appropriateness level of a business by looking at certain parameters or eligibility criteria including profit analysis, pay back period (PP) analysis, return on investment (ROI) analysis, and investment analysis. Moreover, investment analysis includes Net Present Value (NPV), Net Benefit-Cost Ratio (Net B/C), and Internal Rate of Return (IRR). From these criteria, it can be concluded that the business feasibility is feasible or not to be continued.

\subsection{Business analysis}

In the business analysis, production costs, business revenues and income obtained from fishery businesses were examined to be main data. Business analysis consists of balance analysis of revenues and costs, analysis of payback period (PP) and analysis of return of investment (ROI) (Febrianto, 2008).

\subsection{Profit analysis}

In this analysis, calculations were carried out to determine the amount of profit obtained from a business activity. Profit analysis can use the formula:

$$
\Pi=\mathrm{TR}-\mathrm{TC}
$$

$$
\begin{array}{ll}
\Pi & =\text { Profit } \\
\mathrm{TR} & =\text { Total revenue } \\
\mathrm{TC} & =\text { Total cost }
\end{array}
$$

Determination:

TR > TC: Profit generating

$\mathrm{TR}<\mathrm{TC}$ : No profit generating

$\mathrm{TR}=\mathrm{TC}:$ Impasse or deadlock

\subsection{Analysis of the balance of revenue and costs (revenue-cost ratio)}

Analysis of the balance of revenue and costs (revenue-cost ratio) is carried out to determine how far each IDR value of costs used in business activities could provide a number of revenue values as a benefit from a business. The most profitable business activities have the greatest $R / C$ value. The R/C calculation uses the formula:

$$
\mathrm{R} / \mathrm{C}=\frac{\mathrm{TR}}{\mathrm{TC}}
$$

$\mathrm{R} / \mathrm{C}>1$ : Profit generating

$\mathrm{R} / \mathrm{C}<\mathrm{TC}$ : No profit generating

$\mathrm{R} / \mathrm{C}=\mathrm{TC}$ : Impasse or deadlock 


\subsection{Payback period (PP) analysis}

Payback period (PP) is the period required to recoup investment expenses using cash flow. It is used as the ratio between investment expenditure and profits, the result is a unit of time (Umar, 2007). PP calculation was done with the formula:

$$
\mathrm{PP}=\frac{\text { Investment value }}{\text { Profit }} \times 1 \text { year }
$$

\subsection{Return on investment (ROI) analysis}

ROI is the ability of capital invested in all assets to generate net profit from a business being run. ROI calculation uses the formula:

$$
\mathrm{ROI}=\frac{\text { Profit }}{\text { Investment }} \times 100 \%
$$

\subsection{Investment analysis}

In the investment analysis of the purse seine fishing gear, analyzes such as Net Present Value (NPV), Internal Rate of Return (IRR), and Net Benefit Cost Ratio (Net B / C) were carried out.

\section{Net Present Value (NPV)}

NPV is commonly used to assess the benefits of an investment, namely what is the present value of the project's benefits which are stated in IDR. The project is declared feasible to continue if the NPV $>0$, if the NPV $<0$, then the investment is declared not profitable, which means the project is not feasible to be implemented. If the NPV value $=0$, it means that the project is only returning capital or not making a profit and also not losing. According to Nurmalina et al. (2009), the formula used in the NPV calculation is as follows:

$$
\mathrm{NPV}=\sum_{t=1}^{n} \frac{B_{t}-C_{t}}{(1+i)}
$$

$\mathrm{B}_{\mathrm{t}} \quad=$ Profit of a project in year-t

$\mathrm{C}_{\mathrm{t}} \quad=$ Project cost in year- $\mathrm{t}$

$\mathrm{i} \quad=$ interest rate prevailing

$\mathrm{t}=$ project engineering age

\section{The net benefit cost ratio (Net $B / C)$}

The net benefit cost ratio $(\mathrm{Net} B / C)$ is the ratio between the present value of net profits in a year where the net profit is positive and the net profit is negative. The formula used is:

$$
\begin{array}{ll} 
& N e t B / C=\frac{\sum_{t=1}^{n} \frac{B_{t}-C_{t}}{(1+i)}\left(B_{t}-C_{t}\right)>0}{\sum_{t=1}^{n} \frac{B_{t}-C_{t}}{(1+i)}\left(B_{t}-C_{t}\right)<0} \\
\mathrm{~B} & =\text { benefit } \\
\mathrm{C} & =\text { cost } \\
\mathrm{i} & =\text { discount rate }
\end{array}
$$


$\mathrm{t} \quad=$ periode

With eligibility criteria:

$B / C>1$, efforts are worth running

$\mathrm{B} / \mathrm{C}<1$, unsuitable effort

$B / C=1$, then the implementation decision depends on the investor

\subsubsection{Internal rate of return (IRR)}

IRR is the value of the interest rate which makes the NPV of the project equal to zero. IRR could be defined as the interest rate where the present value of total costs equals the present value of total revenues. Therefore IRR is also considered as the level of net return or investment, where the positive net benefits are reinvested in the following year and get the same rate of return and are given interest for the remaining life of the project. According to Nurmalina et al. (2009) the IRR formula is as follows:

$$
I R R=i_{1}+\frac{N P V_{1}}{N P V_{1}-N P V_{2}}\left(i_{2}-i_{1}\right)
$$

$\mathrm{NPV}_{1} \quad=$ NPV positive

$\mathrm{NPV}_{2} \quad=\mathrm{NPV}$ negative

$\mathrm{i}_{1} \quad=$ discount rate obtains NPV positive

$\mathrm{i}_{2}=$ discount rate obtains NPV negative

With eligibility criteria:

- If IRR > interest rate occurs, then the effort is declared eligible

- If the IRR <interest rate applies then the stated effort is not eligible

\section{Results and Discussion}

\subsection{Composition of Catch}

The composition of the catch were obtained from the fishing operation using the purse seine including flying fish (Decapterus russelli), the red-tailed flying fish (Decapterus tab), tuna (Euthynnus affinis), lemuru (Sardinella lemuru) and peperek (Leiognathidae). The main catch from purse seine gears were flying fish and tuna, where in 2018 flying fish reached $4625 \mathrm{t}$ and tuna reached $4867 \mathrm{t}$.

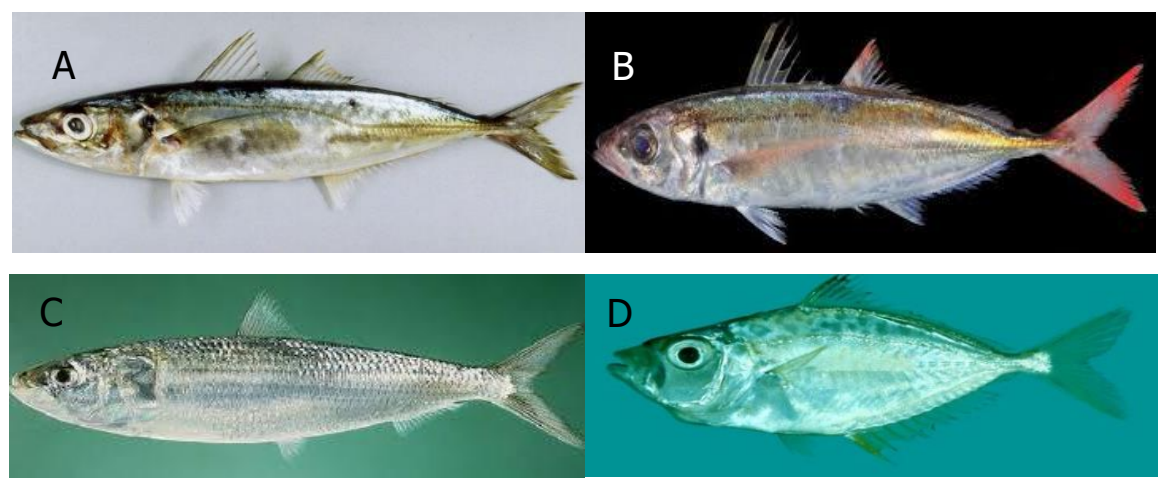




\section{$\mathrm{E}$}

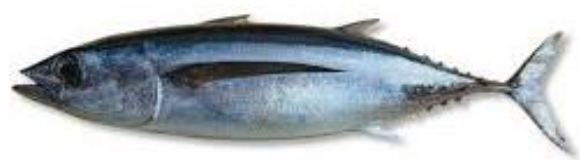

Figure 1. (A). Decapterus ruselli, (B).Decapterus tabl, (C). Sardinella lemuru, (D). Leiognathidae, (E). Euthynnus affinis

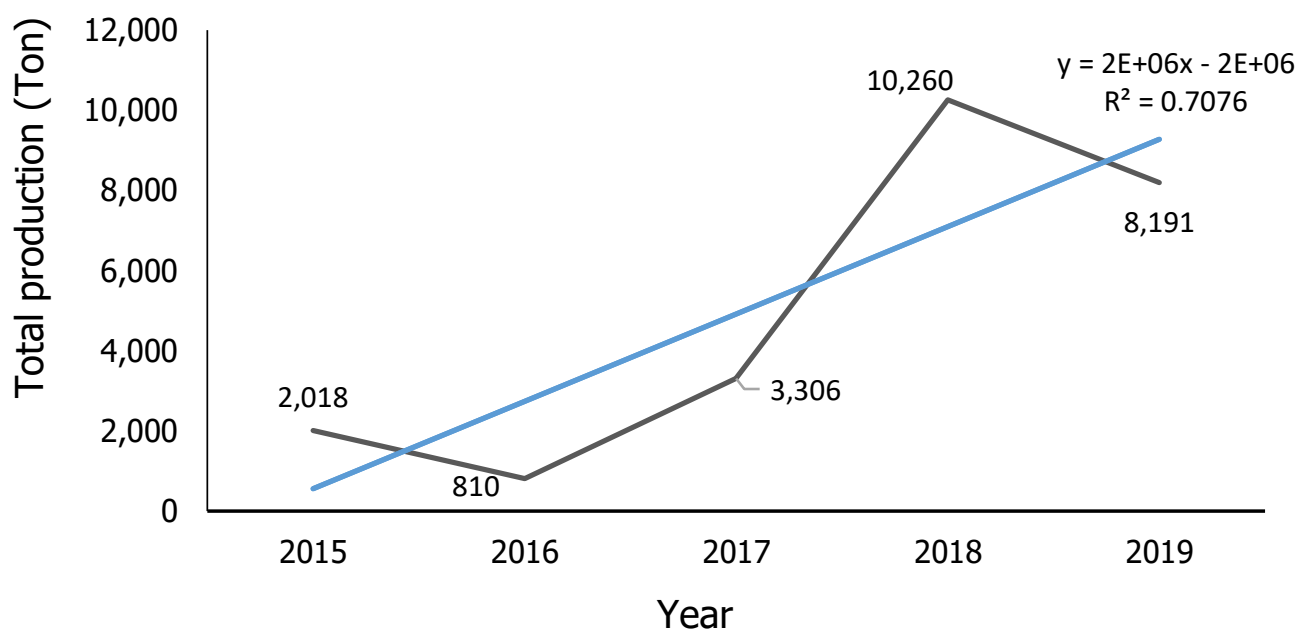

Figure 2. Production Value of Purse Seine Fish per year (Ton)

Production results for the last five years have been unstable where production in 2015 was $2018 \mathrm{t}$ and in 2016 there was a decrease to $810 \mathrm{t}$, then in 2017 to 2018, it increased where in 2017 it became 3306 t, and the peak of the increase occurred in 2018 amounting to 10260 tons, in 2019 production again decreased to $8191 \mathrm{t}$.

Table 1 . The average number of trips and the number of purse seine fishermen who go to sea each year

\begin{tabular}{ccc}
\hline Year & The number of trips & The number of fisherman \\
\hline 2015 & 207 & 7278 \\
2016 & 180 & 6709 \\
2017 & 239 & 8365 \\
2018 & 303 & 9235 \\
2019 & 283 & 9050 \\
\hline
\end{tabular}

Unstable production every year was caused by the number of fishing operations that have increased and decreased each year, where the number of trips and the number of fishermen who catch fish also affected production results. Besides, it could also be caused by several factors including the number of purse seine vessels that go to sea and do not. Moreover, the difference in the GT of the ship, the length of the net, and the number of crew members on the ship also affected the catch which caused the fish obtained from each purse seine vessel to be different on each ship (Hermawan, 2006). The rest factor, the extreme weather such as heavy rainfall and high waves were to be considered which genereted a trouble. According to Hermawan et al. (2016), the length of the purse seine net has the most significant effects because the longer the net length is the optimal the catch. Ship GT affects the catch, namely the larger the GT of the ship, the greater the capacity of the fish catch that could be carried. The shape and size of a ship will affect the strength 
of the ship above the sea. Machine PK has the effect that the greater the engine power is used. The number of crew members has an effect on the withdrawal of the purse seine net.

According to Maulidia 2018, The decline of production could be caused by many factors including repair of engine ships and nets as well as high rainfall and erratic weather so that fishermen cannot routinely go to sea. The extreme weather and high waves can affect the amount of catch and fishing effort. According to Limbong (2008), in general fishery activities are carried out every day throughout the year, however the catch is influenced by the fishing season and weather. This condition is related to the west and east monsoons. The west season usually occurs from December to April, while the east season usually occurs from June to October. However, due to the influence of El Nino, this situation can no longer be predicted because winds and waves can come suddenly. In the eastern season, the catch from fisheries is very abundant, on the other hand, in the western season the catch is small.

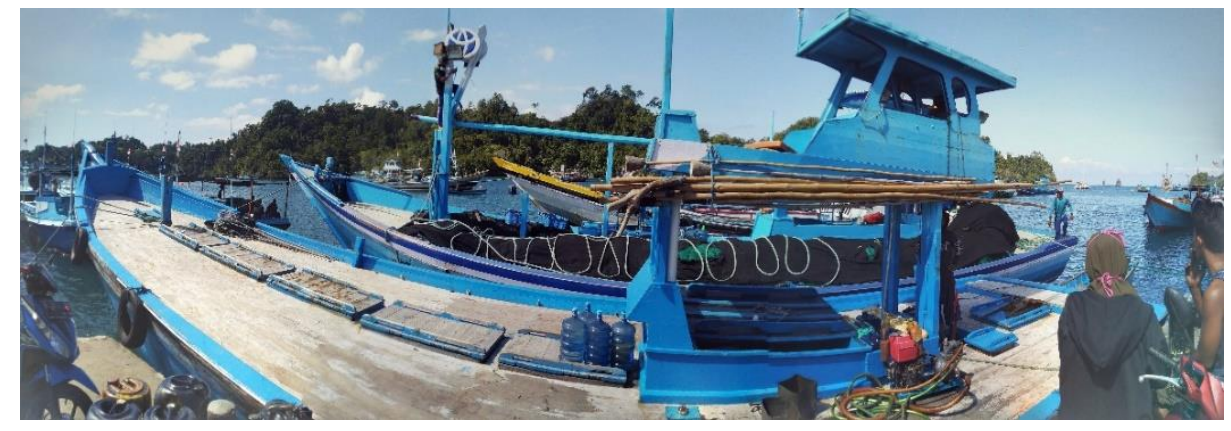

Picture 3. Purse seine ship in Sendangbiru

\subsection{Business feasibility analysis}

According to Nanda (2011), financial analysis is carried out to assess the effects of activities on the perpetrators of the activity and other parties who participate in the fishing effort. Financial analysis aims to produce a plan that describes the financial situation and sources of funds for various participants in the activity and the activity itself. Business analysis is generally used to evaluate the activities of a business in a certain period. Usually the business analysis uses a one-year period approach.

Business analysis on purse seine vessels was carried out to determine the business activities of purse seine fishing gear in Sendangbiru. In conducting business analysis, several analytical approaches are needed, namely business income analysis, Net B/C analysis, Payback Period, ROI, NPV and IRR. A business analysis are consisted of investment, fixed costs, variable costs and revenues. Investment has a relatively long term in various business fields (Kashmir and Jakfar, 2010).

\section{Investments}

Investment is the initial cost incurred in doing the business to be run. Details of the investment costs for purse seine vessels operating in Sendangbiru could be seen in Table 2.

Table 2. The components of the purse seine ship business investment in Sendangbiru

\begin{tabular}{llrr}
\hline \multicolumn{1}{c}{ Description } & Volume & Price (IDR) & \multicolumn{1}{c}{ Total (IDR) } \\
\hline Ship & 2 units & 488600000 & 977200000 \\
Machine & 2 units & 73000000 & 146000000 \\
\hline
\end{tabular}




\begin{tabular}{lcrr}
\hline Genset & 1 units & 5700000 & 5700000 \\
Catching gear & 1 set & 366000000 & 366000000 \\
Tank (Jerigen) & 10 units & 94000 & 940000 \\
Lamp & 1 set & 7240000 & 7240000 \\
Bucket & 100 units & 90000 & 9000000 \\
GPS & 1 units & 2000000 & 2000000 \\
Communication & 1 set & 1000000 & 1000000 \\
equipment & & & \\
\hline Total & & 1515080000 \\
\hline
\end{tabular}

Based on Table 2, it is known that the amount of investment spent in the purse seine ship business in Sendangbiru was IDR 1515080 000. The investment costs included the construction of two vessels measuring $25 \mathrm{GT}$, including one fishing gear vessel that has a length of $17 \mathrm{~m}$ and a width of $4.5 \mathrm{~m}$ and another vessel for fishing has a length of $16 \mathrm{~m}$ and a width of $4.5 \mathrm{~m}$ with a fish capacity reaches 20 tons. The ship's engine uses eight-cylinder Nissan on each ship, the purse seine fishing gear has a net length of $300 \mathrm{~m}$ and a width of $50 \mathrm{~m}, 1$ generator set, 10 jurigen, 1 set of lights, 100 baskets, 1 GPS and communication tools 1 set. According to Hermawan (2006), investment is an investment for one or more assets owned and usually has a long term with the hope of getting benefits in the future.

\subsubsection{Fixed costs}

Fixed costs are costs that are always incurred regardless of whether the purse seine fishing operation carried out or not. The fixed cost components for a period of one year can be seen in table 3.

Table 3. Components of fixed costs for the purse seine ship business in Sendangbiru

\begin{tabular}{lcc}
\hline Description & Age (Year) & Total \\
\hline Ship maintenance & 1 & 26000000 \\
Catching gear maintenance & 1 & 24400000 \\
Machine maintenance & 1 & 15000000 \\
Shrinkage of ships & 10 & 97720000 \\
Capture gear depreciation & 4 & 91500000 \\
Machine shrinkage & 5 & 29200000 \\
Licensing & 1 & 1500000 \\
\hline Total & & 285320000
\end{tabular}

In Table 3 shows that fixed cost was spent for 1 year by purse seine ship as much as IDR 285 320 000. The fixed cost was spent including maintenance cost, and shrinkage of ships, machine, capture gear, and license cost. According to Esa and Putra (2016), fixed cost is a cost caused by the use of resources for production process. Moreover, fixed cost relatively is not changed even though the production changes.

\subsubsection{Variable costs}


Variable costs are costs incurred during fishing activities by purse seine vessels. The amount of the variable cost is determined by the number of fishing efforts made. Details of variable costs in a one year period could be seen in Table 4.

Table 4. Components of the variable cost of the purse seine ship business in Sendangbiru

\begin{tabular}{lrrr}
\hline \multicolumn{1}{c}{ Description } & \multicolumn{1}{c}{ Volume } & Price (IDR) & \multicolumn{1}{c}{ Total (IDR) } \\
\hline Fuel & 52.200 litres & 5150 & 268830000 \\
Ice & 18.000 units & 12000 & 216000000 \\
Food supplies & 180 years & 960000 & 172800000 \\
Clean water & 180 years & 48000 & 8640000 \\
Retribution & 12 years & 3569866 & 42838395 \\
\hline Total & & & 709108395 \\
\hline
\end{tabular}

Based on Table 4, it is known that the variable cost incurred for one year was IDR 709108 395. Variable costs consisted of diesel fuel, ice, fishermen's food supplies, clean water and user fees. Daily purse seine fishermen in Sendangbiru uses boats measuring 20 to 30 GT with 30 to $35 \mathrm{crew}$ members. The operational costs were around 3 to 6 million for one day fishing, in one month daily purse seine vessels generally only carried out 15 to 20 fishing days and the remaining time was used for repairing vessels and fishing gear. According to Esa and Putra (2016), variable or variable costs are costs incurred by business actors, the amount of which is different for each trip and year. Variable costs are influenced by the amount of production available.

\subsubsection{Income}

In the business feasibility analysis, income is a determinant of the assessment of the feasibility of a business. It is because every effort made is aimed at getting income that can cover operational costs. Based on the research results, the purse seine boat business income in Sendangbiru could be seen in Table 5.

Table 5. Income of fishing business using purse seine fishing gear at UPT PPP Pondokdadap Malang

\begin{tabular}{lrrrrr}
\hline & \multicolumn{5}{c}{ Year (Thousand IDR) } \\
\cline { 2 - 6 } Description & 2015 & 2016 & 2017 & 2018 & \multicolumn{1}{c}{2019} \\
\hline Decapterus russelli & 5310917 & 2195685 & 7459008 & 27991663 & 19679460 \\
Sardinella lemuru & 1056735 & 122491 & 367601 & 1338514 & 7730350 \\
Euthynnus affinis & 5158735 & 3565666 & 13562857 & 35553751 & 14253034 \\
Leiognathidae & 0 & 0 & 72940 & 1137099 & 656086 \\
Decapterus tabl & 425416 & 0 & 1362735 & 1634527 & 519465 \\
\hline Total & 11951802 & 5883841 & 22825139 & 67655554 & 42838395 \\
\hline
\end{tabular}

Table 5 reveals the total sales of fish using purse seine fishing gear at UPT PPP Pondokdadap in the last five years in the amount of thousands of IDR. For more details, the composition of the catch in the form $(\mathrm{kg})$ could be seen in Table 6. This amount is the result of the purse seine fishing gear at the UPT PPP Pondokdadap every year that could be seen in Table 6. 
Table 6. Composition of the catch of purse seine fishing gear in Pondokdadap Malang

\begin{tabular}{lrrrrrr}
\hline \multirow{2}{*}{ Description } & \multicolumn{6}{c}{ Year (Ton) } \\
\cline { 2 - 7 } & 2015 & 2016 & 2017 & 2018 & 2019 & Total \\
\hline Decapterus russelli & 950 & 226 & 1593 & 4625 & 3667 & 11061 \\
Sardinella lemuru & 366 & 41 & 139 & 388 & 2619 & 3553 \\
Euthynnus affinis & 635 & 543 & 1352 & 4867 & 1738 & 9134 \\
Leiognathidae & 0 & 0 & 36 & 184 & 93 & 313 \\
Decapterus tabl & 67 & 0 & 185 & 197 & 74 & 524 \\
\hline Total & 2018 & 810 & 3306 & 10260 & 8191 & 24585 \\
\hline
\end{tabular}

The fish catch using purse seine fishing gear at UPT PPP Pondokdadap was fluctuating every year. Based on Table 5 and Table 6, the next step is to look for the benefits obtained from fishing using purse seine fishing gear at UPT PPP Pondokdadap. According to Nurmalina et al. (2009), looking for profit using the formula:

$$
\text { Profits }=\text { Receipts }- \text { Costs }
$$

The profit could calculated by using the formula above so that the profit results from fishing business using purse seine fishing gear at UPT PPP Pondokdadap Malang could be seen in Table 7.

Table 7. Income from the purse seine fishing gear at UPT PPP Pondokdadap Malang

\begin{tabular}{lrrrrr}
\hline \multirow{2}{*}{ Calculation } & \multicolumn{5}{c}{ Year (Thousand IDR) } \\
\cline { 2 - 6 } & 2015 & 2016 & 2017 & 2018 & 2019 \\
\hline Income total & 11951802 & 5883841 & 22825139 & 67655554 & 42838395 \\
Cost every year & 969420 & 972670 & 978020 & 988720 & 994428 \\
Gross income of the & & & & & \\
entire purse seine & 10982382 & 4911171 & 21847119 & 66666834 & 41843966 \\
ship & 366079 & 163706 & 728237 & 2222228 & 1394799 \\
Income each ship & 183040 & 81853 & 364119 & 111114 & 697399 \\
Ship owner 50 \% & 183040 & 81853 & 364119 & 111114 & 697399 \\
Crews 50 \% 30 each & & & & & \\
\hline
\end{tabular}

Based on Table 7. It is known that the income of fishermen is divided into $50 \%$ owner and $50 \%$ crew members of 30 people. From these results, it could be seen that the income of fishermen in 2015 amounted to IDR 183040 000, in 2016 decreased to IDR 81853 000, in 2017 experienced an increase to IDR 364119 000. The highest was in 2018 which reached IDR 1111114 000, in 2019 there was another decline to IDR 697399 000. According to Esa and Putra (2016), income is the value of money obtained from the sale of fish production which is influenced by the size of the number of fish caught when landed. Income is obtained from the income per kilogram of fish caught 
when landed, the average price of each type of fish per kilo. The amount of revenue is influenced by the productivity of fishing gear, season and fluctuations in fish prices.

\subsubsection{Financial analysis}

Table 8. Results of the analysis of purse seine fishing gear business at UPT PPP Pondokdadap

\begin{tabular}{lr}
\hline \multicolumn{2}{c}{ Financial analysis } \\
\hline Profit & 1394798872 \\
R/C & 43 \\
PP & 13 month \\
ROI & 92 \\
NPV & 90337780072 \\
NET B/C & 61 \\
IRR & $633.8 \%$ \\
\hline
\end{tabular}

Based on table 8, the results of the business and investment analysis above, it is found that the revenue obtained by the purse seine fishing gear was uncertain every year or fluctuating. According to Neliyana et al. (2014) The revenue received by fishermen depends on the fishing season. The fishing season consists of the peak season, medium season and low season. The dry season is the season where the fish caught on land are very minimal. Most revenue is obtained during peak season. According to Lusiani et al. (2018), the catch is affected by the fishing season. This condition is related to the west and east monsoons. The west season usually occurs from December to April, while the east season occurs from June to October.

The results of the business analysis found that the profit from the purse seine fishing gear was IDR 1394798 872, R/C of 43, PP of 13 months and ROI of 92. These results could be determined that the business analysis was feasible because the profits were TR $>T C, R / C>1$, PP of 13 months and ROI had 92 in value. According to Neliyana et al. (2014), components used in conducting business analysis include production costs, business revenues and income derived from fisheries. Business analysis consists of balance analysis of revenues and costs, analysis of payback period (PP) and analysis of Return of investment (ROI). The results of the analysis of investment criteria for purse seine vessels, namely positive NPV, B/C and IRR value was greater than the interest rate, which was $12 \%$. That means the ship business with purse seine fishing gear at UPT PPP Pondokdadap was still feasible to be implemented. According to Neliyana et al. (2014) the strength of fishing communities is the main determinant of capture fisheries activities and the coastal economy because they are the ones who do it directly daily.

\section{Conclusion.}

The purse seine fishery business in Sendangbiru meets the requirements and is still feasible to be implemented. The results of the calculation of business feasibility in the purse seine capture fishery business were NPV of IDR 9337780 072, IRR of $633.8 \%$ and Net B/C of 61. From these results, it could be concluded that in the next few years the purse seine fishery business is still feasible to run and profitable financially. 


\section{References}

Eriyanto. 2007. Teknik Sampling Analisis Opini Publik. Yogyakarta. LKIS. Yogyakarta.

Esa G, Putra AB. 2016. Analisis Faktor-Faktor Yang Mempengaruhi Produksi Dan Pendapatan Nelayan Di Desa Batununggul Kecamatan Nusa Penida. E-Jurnal Ep Unud. 8(5): 1092-1121.

Fattah M, Utami TN, Intyas CA. 2017. Analisis Potensi Dan Peluang Pengembangan Sub Sektor Perikanan Tangkap Laut Di Kabupaten Malang. Economic and Social of Fisheries and Marine. 4(2): 135-143.

Febrianto A. 2008. Di Kabupaten Bangka Provinsi Kepulauan Bangka Belitung : Suatu Pendekatan Sistem Bisnis Perikanan. IPB.

Hermawan D. 2006. The Prospective of Sendang Biru Coastal Zone Development For Integrated Fisheries Industry. Jurnal Protein. 13(2): 203-209.

Hermawan D, Boer M, Dahuri R, Budiharsono S, Ma'ruf WF. 2012. Ikan tuna sirip kuning ( Thunnus albacores) di perairan zona ekonomi eksklusif Indonesia Samudera Hindia Selatan Jawa Timur. Jurnal Harpodon Borneo. 5(1): 1-11.

Hermawan OD, Asriyanto, Sardiyatmo. 2016. Hubungan lama waktu pelingkaran jaring dan penarikan tali kerut terhadap total hasil tangkapan alat tangkap purse seine di Muncar, Kabupaten Banyuwangi, Jawa Timur. Journal of Fisheries Resources Utilization Management And Technology.Management And Technology. 5(2): 1-9.

Kashmir J. 2010. Studi Kelayakan Bisnis. Kencana Prenada Media Grup.

Lusiani, Hendrawan A, Wahikun. 2018. Pengaruh Curah Hujan Terhadap Fluktuasi Produksi Penangkapan Ikan Di Laut (Perairan Cilacap). Jurnal Saintara. 2(2), 1-7.

Limbong M. 2008. Pengaruh Suhu Permukaan Laut Terhadap Jumlah Dan Ukuran Hasil Tangkapan Ikan Cakalang Di Perairan Teluk Pelabuhan Ratu Jawa Barat. Skripsi. Fakultas Perikanan Dan Ilmu Kelautan. ITB. Bogor.

Maulidia L. 2018. Studi Faktor Lingkungan Terhadap Hasil Tangkapan Purse Seine Yang Di Daratkan Di Pelabuhan Perikanan Pondokdadap Sendang Biru Kabupaten Malang Pada Bulan April-Juni 2018. Skripsi, Universitas Brawijaya.

Nanda. 2011. Analisis Kelayakan Restrukturisasi Mesin Pabrik Gula Kremboong, Kabupaten Sidoarjo, Jawa Timur. IPB.

Neliyana, Wiryawan B, Wiyono ES, Nurani TW. 2014. Analisis Kelayakan Usaha Perikanan Pukat Cincin Di Pelabuhan Perikanan Pantai (PPP) Lampulo Banda Aceh Propinsi Aceh (Analysis Financial Fisheries Of Purse Seine In Lampulo Fishing Port Banda Aceh Provinsi Aceh). Marine Fisheries. 5(2): 163-169.

Nurmalina R, Sarianti A, Karyadi A. 2009. Studi Kelayakan Bisnis. Departemen Agribisnis, Fakultas Ekonomi Dan Manajemen. 
Sunariyah. 2004. Pengantar Pengetahuan Pasar Modal (5th Ed.). Cv Alfabeta.

Umar H. 2007. Studi Kelayakan Bisnis (Kedua). PT. SUN.

UPT. PPP Podokdadap. 2019. Data Statistik Pelabuhan Sendang Biru. KKP. 